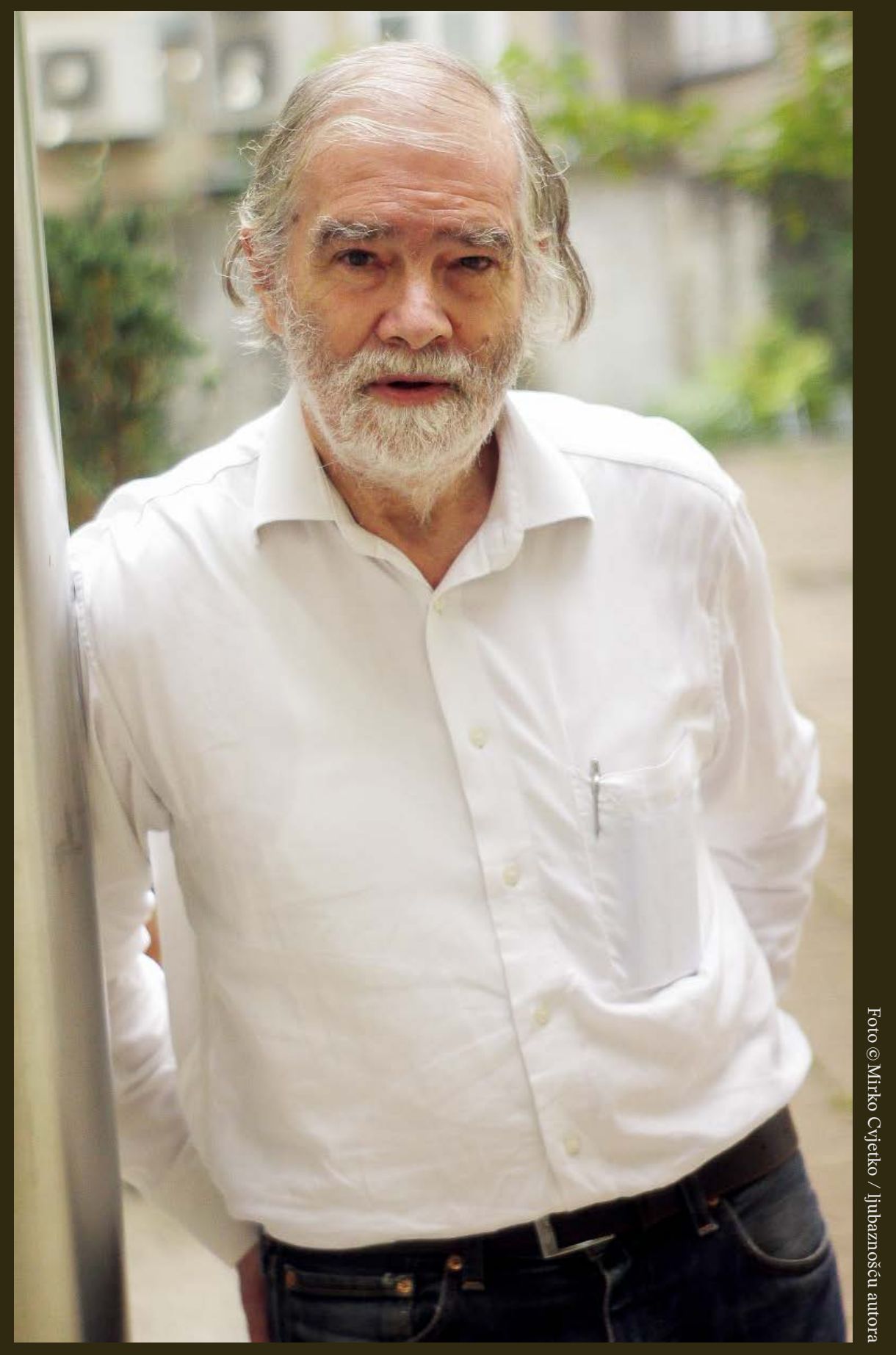

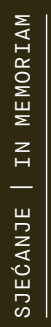




\section{IN ARTIBUS VITA}

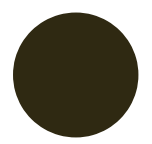

U spomen Tonku Maroeviću

Proteklo je više od pola godine od kako nas je napustio Tonko, čovjek velika znanja i lagana koraka. Ako je za ovu priliku potrebno izdvojiti dvije vrednote koje bi mogle poput dvaju reflektora osvijetliti njegov dragi lik, neka to budu upravo ove: znanje s jedne i lakoća s druge strane. Preludiramo li na Calvinovoj misli iz Američkih predavanja, jedna podrazumijeva drugu: naime, lakoća kao stanje duha ne počiva na poricanju turobne stvarnosti svijeta u kojem nam je suđeno živjeti, već upravo suprotno, u sposobnosti kreativne preobrazbe vlastitoga kritičkog uvida, u volji i umijeću da se rugobno blagoslovi, štetno izbjegava, bolno ugrije, prolazno zabilježi-ukratko, da se egzistencijalno stanje stvaralački kultivira u onome tradicionalnom smislu, koji je stoljećima činio srž pojma humanitas-koncepta koji je u posljednjih pola stoljeća doživio mnoge teorijske udarce, ali od kojeg Tonko, kao ultimus Romanorum, nije htio niti mogao odustati.

U Životu umjetnosti Tonko Maroević bio je prisutan od prvoga broja. Te 1966. godine Maroević je netom zaposlen kao asistent na Odsjeku za povijest umjetnosti, s objavljenom prvom poetskom zbirkom. Učestalo počinje pisati i o umjetničkim zbivanjima-upravo članke objavljene u prvih nekoliko godišta našeg časopisa te one koje je istodobno pisao za Telegram ubrzo će okupiti u izdanju Polje mogućeg (1969.), svojoj prvoj zbirci likovnokritičkih tekstova. Kao mlad i perspektivan kolega, članom uredništva postaje već 1968. i ostaje sve do 1990., dakle više od dvadeset godina. U tom je razdoblju kratkotrajno bio i glavni urednik (1987./1988.), a i u sljedećim godinama ostao je vezan uz časopis čašću člana uredničkog savjeta.

\section{Ivana Mance}

Institut za povijest umjetnosti, Zagreb 
Tonko Maroević u Životu umjetnosti pisao je kroz četrdeset godina-do sredine devedesetih kontinuirano, a potom povremeno. Njegovo se pisanje dakle provlači kroz tri desetljeća trajanja ove publikacije-podsjetimo se, prve u nas namijenjene komentiranju i promišljanju aktualne likovne kulture (i umjetnosti), kako je naime glasio dugogodišnji podnaslov časopisa, odajući prosvijećeni koncept generacije njegovih osnivača. S Božidarom Gagrom na čelu kroz prvih nekoliko godina, Život umjetnosti je okupio uredništvo i suradnike vezane uz zagrebački Odsjek za povijest umjetnosti i tada pridruženi Institut, a izbor tematskih blokova odaje jasno postavljene interese časopisa: diversifikacija načela povijesnoumjetničkog vrednovanja i afirmacija regionalnih specifičnosti, urbanizam i povijesni razvoj prostora, kultura spomenika, dizajn i fotografija, nadrealizam i apstrakcija... Ukratko, kritičko tumačenje prošlosti u funkciji razvojnih potencijala sadašnjosti, aktivan pristup novim fenomenima, sve u skladu s konstruktivnim, modernizacijski usmjerenim duhom vremena. Osim izdvojenih tematskih blokova, časopis ima i redovni, kroničarski dio, tj. prate se nova izdanja i izložbe, a za posebnu rubriku prevode se i teorijski eseji-kroz nešto više od dvadeset godina kontinuiranog prevođenja Život umjetnosti iznjedrio je antologiju kanonskih tekstova, koja svjedoči o recepciji ideja u vremenu, ali i o dobrim navikama čitanja.

Dakle, u ovakvom se ozračju Tonko uključuje u rad časopisa. Njegovi doprinosi tijekom prvih nekoliko godina primjereni su početničkom položaju: piše pretežno recenzije novih izdanja starijih kolega, pa je tako njegov prvi članak o knjizi Krune Prijatelja o Blažu Jurjevu-uzornom djelu po pitanju pristupa koji određeni, do tada više ili manje anonimni slikarski korpus stilski interpretira kao autorski profiliran opus „domaćeg majstora”. Uslijedit će rezime pojedinačno objavljenih radova Cvite Fiskovića o ljetnikovcima, odnosno o povijesnim literarnim izvorima za renesansnu kulturu ladanja te prikaz knjige Svetozara Radojčića o srednjovjekovnom srpskom slikarstvu. Možemo pretpostaviti da su to bili radni zadaci; pa ipak, ovi su rani radovi i odraz specifičnog senzibiliteta, koji nije jednostavno svestran, već je od početka profiliran za sve što proizlazi iz antičke tradicije, odnosno, kako sam piše u prikazu Radojčićeve knjige, što „slijedi neprekinutu antiknu nit”. I u kasnijim će godištima Tonko povremeno prikazivati djela svojih kolega i prijatelja: Marije Planić-Lončarić, Igora Zidića, Jelene Uskoković, Mladena Pejakovićadobar je to običaj pisanja o štivu različitih žanrova i tematika, neovisno o tome je li u temu neposredno upućen ili je tek zainteresirano prati izdaleka.

Druga skupina tekstova koje je Tonko Maroević objavio u Životu umjetnosti osvrti su na aktualna umjetnička, odnosno izložbena zbivanja, koja se u časopisu ažurno prate. Premda su članci ove vrste ovdje tek kap u Tonkovu bibliografskom oceanu, iz njihova se slijeda ipak ponešto može zaključiti. Osim što odaju stalni interes za pojedine umjetnike (koje nema smisla ovom prilikom nabrajati), osvrti prije svega svjedoče o izmjeni umjetničkih fenomena u vremenu i Tonkovu položaju u njemu. Prvi tekstovi pisani povodom izložbe Ornamentograf Zorana Radovića u Galeriji Studentskog centra te Vasarelyjeve izložbe u Galeriji suvremene umjetnosti male su rasprave o dosezima tzv. programirane umjetnosti koje odražavaju još uvijek prisutno ozračje neoavangardi, no već idući članak posvećen legendarnoj izložbi Ljerke Šibenik u GSU-u najavljuje doba novih pristupa. Progresivna zbivanja u Galeriji SC-a Tonko će zainteresirano pratiti i povremeno kritički komentirati, ali ne u našem časopisu. Što se tiče radikalnih konceptualnih i inih praksi, primjerice američkog pop-arta, poznato je da Tonko nije bio njihov apologet, već trezveni promatrač, pa će tako o ovim pojavama pisati prvenstveno načelno, promišljajući povijesni razvoj umjetnosti, dok će komentari pojedinačnih izložbi biti rjeđi.

U tom svjetlu iznimno je vrijedan prikaz spektakularne rimske izložbe Contemporanea (1973./1974.), održane u prostorima podzemnog parkirališta ispod nekadašnjeg hipodroma Ville Borghese, čiji je središnji dio koncipirao tada mladi Achille Bonito Oliva, ponudivši svoju verziju presjeka suvremenosti. Ironičan 
spram tropa kraja umjetnosti, svjestan eficijentne sprege umjetnosti i tržišta, čija logika „kapitalizira” i posvema bestjelesna očitovanja, kao i najbuntovniji poklič, Tonko podastire kompetentan, široko informiran i duhovito napisan komentar izložbenog koncepta i produkcije. Čak i u situaciji malog do umjerenog entuzijazma spram većine izloženih djela, spreman je lučiti vrijednosti, i to bez, kako sam piše, apriorne diskriminacije pa jasno izdvaja nepobitne doprinose pop-arta, neodadaizma, novog realizma, minimalizma, konceptualno-lingvističkih rješenja itd. Kada je riječ o preferencijama, uvijek će mu biti bliži analitički negoli neorealistički pristupi; europska tradicija negoli američka; što ga opet ne priječi da i unutar načelnih opredjeljenja provodi selekciju. Ukratko, osvrt na spomenutu izložbu svjedoči da je imao izgrađene stavove o svemu što je imao prilike vidjeti i upoznati, koristeći priliku za testiranje usvojenih vrijednosti.

Ono što se nadalje može razaznati na temelju njegova pisanja o izložbama i suvremenim umjetnicima u našem časopisu jest nadolazak pojava koje će se ubuduće klasificirati kao postmoderne, što se može pratiti i u časopisu kao cjelini. Osim osvrta na nekoliko samostalnih izložbi slikara koji se povezuju s tim fenomenima, za ovu priliku izdvajamo tekst o Borisu Bućanu-zapravo monografski prikaz dotadašnjeg Bućanova opusa, o kojem tih godina Tonko intenzivno piše, a koji je odabrao kao svoj prilog baš za tematski blok posvećen osamdesetima. Naime, Bućan pripada generaciji koja je otpočela u umjetničkom ozračju kraja šezdesetih i početka sedamdesetih, ali upravo kao takav idealno zastupa Tonkove stavove po mnogim pitanjima: umjetnik razorne ironije i intertekstualne imaginacije, sklon „brkanju” medija i žanrova te travestiji svake vrste, uklopio se u vladajuće ozračje bez pravljenja ikakvog kompromisa, potvrđujući Tonkovo uvjerenje da samo snažna autorska osobnost može biti subjektom povijesti. Kao tip umjetnika koji je intelektualno nadmoćan, ali i bitno likovan, Bućan za Tonka predstavlja idealan izlaz iz uvelike frustrirajućih sedamdesetih i znak je svojevrsnog optimizma koji pobija teze o „kraju umjetnosti”. I napokon, Bućanov poetički kontinuitet teze o oštrim lomovima i radikalnim obratima svodi na pravu, kritičku mjeru, opravdavajući Tonkovu skepsu prema svakom imperativu novosti.

Međutim, vlastite je poglede i teorijska promišljanja o umjetnosti i likovnoj kritici Tonko Maroević prvenstveno iznosio u zasebno pisanim studijama, koje se mogu izdvojiti kao treća skupina njegovih tekstova napisanih za Život umjetnosti. Čini se upravo proročkim da je prvi takav prilog upravo studija o Giuliju Carlu Arganu, objavljena kao uvod uz prijevod njegova eseja, inače drugog od sveukupno tri prevedena u časopisu. Kako će godine prolaziti, i sam će Tonko uviđati koliko je misao ovog talijanskog povjesničara umjetnosti, kritičara i javnoga lijevog intelektualca, kod kojega je proveo i svoj prvi studijski boravak u Rimu (1973./1974.), za njega bila formativna. Prisjećajući se na drugom mjestu svoje mladalačke nepomirljivosti spram Arganovih spekulacija o povijesnom kraju umjetnosti u društvu koje živi svoju tehnološku utopiju, dolazi do tek naizgled samorazumljivoga zaključka, koji odaje temeljnu bliskost pozicija. Pišući naime o stanju umjetnosti krajem devedesetih godina („Umjetnost danas”), Tonko pledira za umjetnost utemeljenu u povijesnoj svijesti, umjetnost koja „baš kao izraz određenoga trenutka, konstelacije, konteksta, smije računati na kasniji odjek”, koja „ukoliko se različitošću ne odredi prema onome što mu je prethodilo, u punom smislu riječi zapravo i ne postoji”. A što drugo, ponovimo to ovdje još jednom, Arganov koncept umjetnosti kao projekta i jest doli razumijevanje umjetnosti kao prakse koja se, reflektirajući o minulome i projicirajući se u buduće, povijesno ostvaruje u sadašnjemu? Koja je imanentno povijesna upravo stoga što je vodi vrijednosno motivirana namjera? I koja upravo zbog relativne autonomnosti svojeg položaja može slobodno svjedočiti o poteškoćama i neuspjesima svojih nastojanja, negirajući determinizam sudbine i potvrđujući humanitas egzistencije? U spomenutom uvodu Tonko pojašnjava narav Arganova dijalektičko-materijalističkog historicizma te načela njegove likovnokritičarske metode; ističe kombiniranje „imanentnih” analiza djela s jedne i društveno-povijesnu kontekstualizaciju s druge strane, a Arganu se 
vraća i u opsežnom referatu o metodologiji likovne kritike („Između slike i riječi”). Uvažavajući generacijske specifičnosti, kao i razlike karijernih putova, iz današnje nam se perspektive čini da su sličnosti između učitelja i učenika daleko veće negoli razlike i da govoreći o Arganovoj, Tonko zapravo govori o vlastitoj metodi mišljenja i pisanja o umjetnosti. I kod njega su istodobno na djelu postupci tzv. imanentne analize umjetničkog djela kao samosvojna, nesvodiva fenomena, ali i shvaćanje djela kao povijesnog događaja, koji stoji u čvrstoj vezi s izvanumjetničkom zbiljom, kao i sa zbiljom historiografskog diskursa unutar kojeg se razmatra. Bilo da kreće od estetičkih načela bilo od subjektivne percepcije, kritika „svoj legitimitet mora potvrditi odnosom prema povijesti, i to prema povijesti vlastite discipline i prema povijesti predmeta kojim se bavi”. Kreativni prostor kritike je „određen vlastitim povijesnim shvaćanjem sadašnjeg trenutka” i njezin je stoga „pravi zadatak pružiti modele upotrebe umjetnosti, i to ne kao priprema neke buduće povijesti nego kao povijesna svijest na djelu". Naspram dokse koja nameće sliku sveprisutna promotora lijepih umjetnosti (i književnosti), baš na ovom mjestu važno je istaknuti da je Tonko bio prije svega povjesničar umjetnosti. Njegovo pisanje o umjetnosti, bez obzira na to kako se žanrovski profilira, utemeljeno je prvenstveno u povijesti umjetnosti, odnosno znanju što ga ona podrazumijeva kao akademska disciplina. Bez obzira na to je li riječ o kritici, monografskom tekstu ili studiji, umjetničko djelo ili skupina djela uvijek se promatra kao povijesni fenomen-ne samo u smislu stilske identifikacije nego upravo u smislu djela kao povijesnog događaja u kojem se odražava uspjeh ili slom zacrtanog projekta, čije se pouke prenose u budućnost. Kao tip povjesničara umjetnosti koji se osjećao obveznim ideirati umjetnost kao povijesnu cjelinu, Tonko je pisao i sintezne preglede te studije, od kojih se nekoliko nalazi i u ovom časopisu: studija o umjetnosti sedamdesetih („S onu stranu zaglavnog kamena”), već spomenuta studija o umjetnosti devedesetih („Umjetnost danas”), kao i studija o umjetničkoj produkciji nastaloj u vremenu, odnosno kontekstu Domovinskog rata („Nemezis protiv Mimezisa”)-još uvijek jedan od rijetkih tekstova na ovu temu; tu je referat o pedesetima održan u okviru skupa posvećenog tome desetljeću („Red i rez”). Napokon, svakako treba podsjetiti i na esej „Krleža prema Meštroviću”, pisan povodom Krležine smrti, koji uz još jedan članak o famoznom kiparu („,Kipar kao junak svoga doba") u Životu umjetnosti predstavlja Tonkovo kontinuirano interpretativno bistrenje raznih sastavnica modernističkog kanona.

Bibliografija Tonka Maroevića u Životu umjetnosti jest pars pro toto opusa koji je tek potrebno u cjelini sagledati. Koliko nas god sjećanje na njegovu osobu ispunjava poštovanjem i ljubavlju, povijesno značenje djela nadilazi razinu personalne aure. Činjenica da su u trenutku kada je počinjao svoj profesionalni put humanističke vrijednosti već bile u krizi (kao što vjerojatno uvijek već i jesu) formirala je njegov stoički habitus - trezveno prihvaćajući dijagnoze vremena, nastavio je brižno zidati svoju duhovnu kuću, ne nasjedajući na obećanja progresa. Tonko nije bio buntovnik, već čuvar vrijednosti i čovjek zajednice, ali temelji njegova mišljenja i djelovanja oduvijek su počivali na bitno modernoj kritičkoj svijesti. Dobro je to imati na umu kad se budemo pozivali na njegov lik i djelo. Kako će se njegov rad identificirati i koristiti, govorit će mnogo i o nama. 


\section{žIVOT UMJETNOSTI}

